GRAŻYNA TEUSZ

Uniwersytet im. Adama Mickiewicza

w Poznaniu

\title{
DOŚWIADCZENIE DOMU RODZINNEGO W NARRACJACH (AUTO)BIOGRAFICZNYCH OSÓB Z RODZIN POLSKICH NA EMIGRACJI
}

\begin{abstract}
AвSTRACt. Teusz Grażyna, Doświadczenie domu rodzinnego w narracjach (auto)biograficznych osób z rodzin polskich na emigracji [The Experience of the Family Home in the (auto)Biographical Narratives of Persons from Polish Families in Emigration]. Studia Edukacyjne nr 50, 2018, Poznań 2018, pp. 321-330. Adam Mickiewicz University Press. ISSN 1233-6688. DOI: 10.14746/se.2018.50.21
\end{abstract}

The subject of the article is to present the experience and image of a family home that Polish family members have in exile. The direct area of reference presented on the basis of conducted (auto)biographical interviews is the German cultural and social context.

Key words: family, family home, (auto-)biographical narration, emigration

\section{Wprowadzenie}

Celem artykułu jest przedstawienie problematyki związanej z doświadczeniem domu rodzinnego przez członków rodzin polskich na emigracji. Kontekst emigracyjny, społeczno-kulturowe uwarunkowania i cechy otoczenia wyznaczają szczególną postać funkcjonowania rodziny, są najważniejszym zewnętrznym czynnikiem oddziałującym na funkcjonowanie systemu rodzinnego i jakość życia poszczególnych osób. Stwarzają one dla funkcjonowania rodziny i jej członków zróżnicowane możliwości, projektują sui generis bardzo heterogeniczne scenariusze relacji, które mają miejsce między tymi zewnętrznymi determinantami a jednostką. Podstawowym źródłem wiedzy o tychże zachodzących interakcjach, o tym jak stymulują one obraz domu rodzinnego oraz o treści doświadczeń rozpiętych między rzeczywistością rodziny pochodzenia, własnym w niej funkcjonowaniem a świadomością, samooceną i funkcjonowaniem w aktualnym kontekście, 
emigracyjnego usytuowania rodziny, staną się (auto)biograficzne narracje osób z rodzin polskich, żyjących na obszarze Niemiec.

\section{Narracja (auto)biograficzna \\ - cechy dystynktywne}

Koncentracja badań biograficznych następuje na życiu oraz indywidualnym świecie konkretnej jednostki, na podmiotowo doświadczanych i przeżywanych sytuacjach, na treści oraz historii jej codziennych aktów świadomościowych oraz intencjonalnych. Nie pozostają one w izolacji od całego kontekstu społeczno-kulturowego. Tkwią silnie w ramach dynamicznego, interkulturowego procesu oddziaływania różnorakich czynników, wielości dotykających jednostkę impulsów i stymulatorów. Biograficzna perspektywa badawcza, której wyznacznikiem staje się narracja (auto)biograficzna, przedmiotem eksploracji czyni zatem indywidualny przypadek, indywidualną historię życia, powiązaną wielorakimi zależnościami ze społeczną i kulturową rzeczywistością. Narracja jest opowieścią podejmowaną z jednostkowej perspektywy, a jej treścią stają się niepowtarzalne, bardzo osobiste, niekiedy wręcz intymne doświadczenia, doznania, spostrzeżenia i przeżycia. Jest sposobem rozumienia rzeczywistości, czy ujmując rzecz precyzyjniej - próbą deskrypcji świata poprzez własne w nim bycie, a zatem próbą wyrażenia osobistej jego percepcji i związanych z tym przeżyć. Jak zauważa Jerzy Trzebiński: „konstruowanie opowiadania jest formą społecznego konstruowania znaczenia faktów"1 ${ }^{1}$. Narracja porządkuje i ogarnia rozumiejąco otaczający świat. Co jednak najważniejsze, nie tylko go opisuje, analizuje i interpretuje, ale także w określony sposób go konstruuje, niejako ustanawia jego świadomościową autoreprezentację.

Dochodząca do głosu w narracji optyka subiektywnego doświadczenia, która przyjmuje postać sui generis samodoświadczenia ja, staje się, jak zauważa Maria Straś-Romanowska wyrazem

"logiki" indywidualnego doświadczenia (systemu znaczeń, filozofii życia, etosu), obiektywizowanej w realnej formie życia (wyborach życiowych, celach, zaangażowaniach itp.), w kontekście biograficznym, środowiskowym, kulturowym².

Świat zostaje w procesie poznawczego ujmowania, intelektualno-emocjonalnego waloryzowania i aksjologicznej oceny niejako "przeniesiony" z płaszczyzny obiektywnej na subiektywną,

${ }^{1}$ J. Trzebiński, Problematyka narracji we wspótczesnej psychologii, [w:] Narracja. Teoria i praktyka, red. B. Janusz, K. Gdowska, B. de Barbaro, Kraków 2008, s. 13.

${ }^{2}$ M. Straś-Romanowska, Psychologiczne badania narracyjne jako badania jakościowe $i$ ich antropologiczne zaplecze, [w:] Tamże, s. 62. 
zawiera (...) cechy specyficzne tyko dla danego podmiotu, nie jest „światem samym w sobie”, lecz "moim”, "twoim”, "naszym" światem, światem, który jawi się jakiejś podmiotowości ${ }^{3}$.

Doświadczenia i przeżycia, które pojawiają się w narracyjnej opowieści, zostają niejako na nowo zaktualizowane, tym razem jednak nie w planie ich ontycznego, realistycznego zaistnienia, a w płaszczyźnie autobiograficznego obrazu rzeczywistości oraz kształtu własnego życia. Dochodzi do głosu swoista sieć znaczeń i sensów, które stają się czynnikiem uspójniającym treści osobistego doświadczenia. Konstytuuje się swoista postać interpretacji swojego sposobu bycia w określonej rzeczywistości społeczno-kulturowej, indywidualnego „zakorzenienia, osadzenia, zakotwiczenia” w płaszczyźnie życia wspólnotowego, zbiorowego. Ustanawiający się w procesie dynamicznej społecznej interakcji proces stanowi zasadniczy kontekst kształtowania się narracyjnej tożsamości jednostki ${ }^{4}$. Tożsamość narracyjną można by ująć jako wysiłek integrowania różnych planów doświadczeń i przeżyć w perspektywie uzyskiwania całościowego planu jedności, celu i sensu przy podejmowaniu odpowiedzi na pytanie, kim jestem i jakim się staję.

\section{Rodzina jako system. Specyfika emigracyjnego kontekstu}

Rodzina stanowi system, to znaczy odrębny, autonomiczny układ rządzący się swoistymi prawami, który nie jest tylko prostą sumą składających się nań składników czy podejmowanych oraz spełnianych przez poszczególnych jej członków zadań oraz ról. Jest rzeczywistością o charakterze interaktywnym i otwartym, zmieniającą się, podlegającą przekształceniom i różnorakim oddziaływaniom. Systemowe ujęcie rodziny odsłania przede wszystkim prawdę o współtworzącej rzeczywistość świata rodzinnego siatce interakcji, wzajemnych odniesień, wzorów funkcjonowania, mechanizmów i strategii komunikowania.

Z perspektywy systemowej można zatem zauważyć, że system rodzinny będący osobliwą, interpersonalną sferą funkcjonowania człowieka stanowi zarazem środowisko ujawniania się jednostkowych, indywidualnych punktów widzenia, procesów doświadczania siebie i świata, konstruowania jednostkowych opowieści, narracji, które stanowią medium przekazu szerokiej gamy doświadczeń i przeżyć, i które wchodzą następnie w proces „wewnątrzrodzinnego dialogowania"

\footnotetext{
3 Tamże, s. 64.

4 A. Cierpka, Tożsamość i narracje w relacjach rodzinnych, Warszawa 2013, s. 18.

${ }^{5}$ G. Teusz, Rzeczywistość budowana stowami. Narracja jako proces wspóttworzenia tożsamości rodziny polskiej na emigracji, [w:] Badania biograficzne i narracyjne w perspektywie interdyscyplinarnej. Aplikacje - Egzemplifikacje - Dylematy metodologiczne, red. M. Piorunek, Poznań 2016, s. 165.
} 
Konstytuujące się w owym "rodzinnym laboratorium dialogowania" 6 narracje, stanowią swego rodzaju wyznaczniki osobistych, jednostkowych trajektorii, wkomponowanych w całość systemu, jakim jest rodzina. Posiadany przez poszczególne jednostki obraz samego siebie wpisany jest $w$ obraz rzeczywistości rodzinnej, w cechy, przekonania i wartości oraz emocjonalne odniesienia i reakcje organizujące rodziną strukturę życia. Konstytuująca rodzinę realna bliskość tworzących ją podmiotów znajduje przede wszystkim swój wyraz w sieci intensywnych międzyosobowych interakcji . Jednak obok tych wewnętrznych, immanentnie współtworzących system rodzinny wyznaczników, rodzina jako system i poszczególni jej członkowie poddani są intensywnemu oddziaływaniu zewnętrznego kontekstu. Szeroko rozumiana dynamika, interakcja kontekstowa, odzwierciedlająca złożone działania i zachowania ma szczególne znaczenie w przypadku rodzin emigracyjnych. Ów układ zewnętrzny, w którym rodzina jest osadzona i funkcjonuje stwarza złożone spektrum możliwości, trudności, ale także ewentualnych szans i twórczych perspektyw, składników aksjologicznie mocnych, silnych, lub aksjologicznie słabych, neutralnych, obojętnych dla życia rodzinnego $\mathrm{w}$ ramach określonych jej emigracyjnym środowiskiem ${ }^{8}$. Emigracyjny kontekst życia generuje szczególną postać stających przed rodziną, jej członkami wyzwań. Pojawiające się trudności wymagają określonych sposobów radzenia sobie z nimi, rozpoznawania i rozwijania własnych zasobów kompetencyjnych i umiejętnościowych, pogłębionej świadomości celów, które jednostka zamierza osiągnąć. Na bazie złożonej interakcji z emigracyjnym kontekstem społeczno-kulturowym przebiega konstruowanie tożsamości poszczególnych jednostek oraz całego systemu rodzinnego ${ }^{9}$. Proces adaptacji do nowego otoczenia, ustabilizowania statusu bycia w nowych warunkach społecznych uwarunkowany jest wielorakimi czynnikami: motywacją i celami podjęcia decyzji o emigracji, osobniczymi zasobami kompetencji i umiejętności, środowiskiem docelowym ${ }^{10}$. Sytuacja rodziny na emigracji, czynniki społeczno-kulturowe determinujące jej status, związana jest, jak to określa Aleksandra Grzymała-Kazłowska, z określonymi strategiami kulturacyjnymi, którymi są: integracja, asymilacja, separacja ${ }^{11}$. Stanowią one róż-

${ }^{6}$ A. Cierpka, Narracyjna tożsamość jednostki a funkcjonowanie systemu rodzinnego, [w:] Narracja. Teoria i praktyka, s. 379.

${ }^{7}$ G. Teusz, Tożsamość narracyjna rodziny wobec multiinformacyjnej kultury wspótczesności, [w:] Kultura popularna w społeczeństwie wspótczesnym. Teoria i rzeczywistość, red. J. Drozdowicz, M. Bernasiewicz, Kraków 2010, s. 339.

${ }^{8}$ D. Niedźwiecki, Migracje i tożsamość. Od teorii do analizy przypadku, Kraków 2010, s. 111.

${ }_{9}$ G. Teusz, Biograficzna pamięć $i$ tożsamość rodziny, [w:] Rodzina - tożsamość - pamięć = Family - Identity - Memory, red. M. Kujawska, I. Skórzyńska, G. Teusz, Poznań 2009.

${ }_{10}$ Tamże, s. 54-55.

${ }^{11}$ A. Grzymała-Kazłowska, Konstruowanie „innego". Wizerunki imigrantów w Polsce, Warszawa 2007 , s. 27. 
ne sposoby pokonywania różnorakich trudności i barier, do których można zaliczyć: barierę językową, mentalnościową, stereotypizacji negatywnej, etnocentryzmu, nieakceptowanej samotności i wyobcowania, a w końcu izolacji społecznej ${ }^{12}$.

W sytuacji nowego, emigracyjnego kontekstu życia i pojawiających się w związku z tym trudności, zasadniczego znaczenia nabiera kwestia sposobów radzenia sobie z nimi oraz źródeł i form wsparcia psychologicznego, społecznego, ekonomicznego. Wśród czynników, które stanowić mogą o zdolnościach poradzenia sobie z trudnościami wynikającymi z warunków życia na emigracji są pewne dyspozycje, zasoby i zdolności ukształtowane w środowisku systemu rodzinnego. Przedstawione przykłady (auto)biograficznych narracji mają na celu ukazanie, w jakim stopniu i zakresie obraz własnej rodziny i doświadczenie domu rodzinnego stanowi czynnik modelujący stosunek do świata, do emigracyjnej rzeczywistości. Ujawniony przez autorów narracji obraz domu rodzinnego, znaczenie, jakie przypisują oni pojęciu życia rodzinnego odsłania ich indywidualny, niekiedy bardzo osobisty stosunek do wiążących się z tą sferą doświadczeń oraz ich wpływ na relacje ze światem zewnętrznym, z obecnym, emigracyjnym kontekstem sytuacji rodziny.

\section{Doświadczenie i znaczenie domu rodzinnego. Przykłady wywiadów (auto)biograficznych}

W wypowiedziach autorów narracji wątek własnej rodziny oraz obraz i znaczenie domu rodzinnego pojawiają się jako ważny element ich świadomości. Sytuacja w domu rodzinnym staje się w wielu przypadkach tą, która w sposób bezpośredni wpływa na decyzję o emigracji oraz określa jakość początkowej fazy życia na obczyźnie. Rozmówcy tak o tym komunikują:

Kiedy ja byłam dzieckiem, to nie dość, że byty wtedy moje wszystkie choroby, to do tego byty ciagle jakieś problemy typu finansowego, bo jednak w Polsce trzeba było płacić za lekarzy, trzeba było po prostu mieć pieniądze na leczenie i, jak się okazywało, niemałe pieniadze. Mama moja wyjechała do Niemiec, ja byłam z tata sama $i$ ciagle by ten strach, że ja jestem tutaj, jeden rodzic jest ze mna, drugi tam, daleko. Ciagle brak takiej stabilizacji, tego, tego, poczucia takiego bezpieczeństwa po prostu. Przedtem było to, że nie było tych rodziców razem. Teraz, kiedy już od lat jesteśmy my i moi rodzice tutaj w Niemczech, to jest to poczucie tego bezpieczeństwa, bezpieczeństwa finansowego przede wszystkim, że jak już wiem, że mi zabraknie, to będę miała środki, to mam poczucie, że mi, mojej rodzinie, nic się nie stanie (Anna, lat 35).

${ }^{12}$ D. Niedźwiecki, Migracje i tożsamość, s. 84-87. 
Poczatek emigracji to... (dłuższa pauza) bolesne doświadczenia (znowu pauza). Po pierwsze rozłaka $z$ rodzicami, znaczy z mama, bo wyjechałam z ojcem, później grożacy rozpad rodziny. Doświadczenia, no... różnego rodzaju traumatyczne (dłuższa cisza). Samotność, samotność bardzo mocno wtedy doświadczana, poczucie bycia odizolowanym od życia rodzinnego w petni, od wielu takich czynników wptywających na poziom i wartość naszego życia, szczególnie później (Lucyna, lat 34)

Jak to się zaczęło? Mój tata, dwadzieścia lat starszy od mojej mamy, zawsze miat takie wizje, aby wyjechać na zachód, za granicę. W latach osiemdziesiatych wyjeżdżat często sam, potem, któregoś razu wzią moja starsza siostrę i wyjechat. I już nie wrócił. Dla mnie, jako czternastolatki, to byt szok. To było stracenie taty $i$ siostry. Dlugo się nie widzieliśmy, bo nie mogliśmy dostać paszportów. Potem pojawiło się pytanie, co z nami będzie jako z rodzina. Tata postawit warunek: albo mama z nami przyjedzie do Berlina, albo rozwód. Gdy ja to ustyszałam, cały świat jakby się zawalit. Mama posadziła nas przy stole, mnie i młodsza siostrę i zapytała co chcemy. Ja od razu powiedziałam, że chce tate, chcę rodzinę. Dla mnie złaczenie rodziny było na pierwszym miejscu. Tę atmosferę, te trudności w rodzinie, te przeszkody z połaczeniem $z$ tata $i$ siostra bardzo przeżywałam i pamiętam do dzisiaj. Mama tak naprawdę dołaczyła do nas po dwóch latach, bo musiała jeszcze coś pozałatwiać z praca i $z$ mieszkaniem. Czekaliśmy na mamę i kiedy przyjechała do nas, to bardzo to przeżywałam, że straciła pracę w Polsce, że była taka oderwana od ludzi. Widziałam, że brakuje jej tej pracy, a nie znała też języka, zamknęła się w sobie. Ja jako dziecko bardzo to przeżywałam, że tak się stało. Z jednej strony chcieliśmy lepszego życia, ale w rodzinie tak tego nie odczuwałam, że nam się polepszyto. Znaczy tak uczuciowo, emocjonalnie bardzo to przeżywatam. Pamiętam to do dzisiaj (Beata, lat 32).

Przytoczone wypowiedzi wskazują, w jak zasadniczym stopniu decyzja o emigracji i związane z tym okoliczności oddziaływały na całość systemu rodzinnego, na wszystkie jego poziomy i na wszystkich jego członków. Z jednej strony pojawiało się poczucie całkowicie nowej, nieprzewidywalnej sytuacji i możliwych następstw podjętego kroku, uświadomienie sobie mogących zaistnieć zagrożeń, z drugiej - jakieś mgliste, mało skonkretyzowane oczekiwanie tego, co miało nastąpić. Rozmówcy akcentują lęk i niepewność, które towarzyszyły wydarzeniom. Dostrzec można fakt, jak decyzja o emigracji przeformułowuje całość rzeczywistości domu rodzinnego, jak rozlegle dotyka jego ontycznej struktury. Siła wiążących się z tą decyzją doświadczeń i odczuć pozostaje w członkach rodziny właściwie na całe życie. Wynika z tego, jak doniosłą i znaczącą wartością jest dla autorów narracji dom rodzinny, jego niezagrożone trwanie i stabilność. Wydaje się, że wartość ta osadzona jest 
w obszarze prymarnego, pierwotnego doświadczenia, które w szczególny, bardzo osobiście angażujący sposób ustanawia i modeluje określony wzorzec międzyosobowych relacji, całą sferę interpersonalnego funkcjonowania człowieka. Ta siła zakotwiczonego $\mathrm{w}$ domu rodzinnym modelowania rzutuje na obszar doświadczania siebie w swojej podmiotowości, na pewien projekt poznawczego i emocjonalnego przeżywania własnej egzystencji, własnego losu oraz relacji i więzi z drugimi. Rzeczywistość domu rodzinnego staje się wzorcem, modelem relacji oraz swego rodzaju "rodzinnej kultury” jako struktury kształtującej „określone tożsamości i tematy" ${ }^{13}$. Jest także, co podkreślają autorzy narracji, istotnym środowiskiem wsparcia, pomocy wobec licznych zagrożeń i niezrozumiałych sytuacji pojawiających się w świecie zewnętrznym, swego rodzaju barierą ochronną wobec rodzących się w tymże świecie zjawisk. Rodzina, dom rodzinny stają się przede wszystkim środowiskiem, które zaspokaja jedną z podstawowych, dla zdrowego funkcjonowania człowieka, potrzeb psychologicznych - potrzebę bezpieczeństwa.

Zawsze miałem wsparcie $w$ rodzicach. Potem miatem pomoc $w$ żonie, ale cały czas ważne było wsparcie rodziców, którzy cały czas byli w Berlinie i mogłem na nich liczyć. To byto dla nie bardzo istotne, szczególnie w sytuacjach trudnych, jakichś niespodziewanych zawirowań, których, szczególnie w tym pierwszym etapie pobytu tutaj, kiedy wszystko byto nowe, inne, nie brakowato (Robert, lat 39).

Przyjechatem do Niemiec w wieku osiemnastu lat, na rok przed matura, i... no oczywiście teraz to już tu jestem dwadzieścia jeden lat. Mam żonę i trójkę dzieci. $Z$ tej perspektywy trudno to sobie wszystko dokładnie przypomnieć, ale z tego co mam w pamięci, to była nasza wspólna decyzja, rodziców i moja. I tak zawsze byto, zawsze wszystko uzgadnialiśmy razem, zawsze też w różnych trudnych sytuacjach mogłem liczyć na pomoc $i$ wsparcie moich rodziców. Każde wsparcie, także finansowe na początku (Marcin, lat 40).

No i zaczęta się ta praca, zaczęto się regularne życie, zaczęto się regularne zarabianie pieniędzy. Jakoś to pomatu zaczęło się to życie w Niemczech budować, krok po kroku. Było ciężko, niekiedy bardzo ciężko. Ciężkie było to, bo rodziny człowiek nie miat. Nie miało się mamy, nie miało się taty, było się samemu. Wyjechaliśmy bowiem zaraz po ukończeniu studiów i rodzice, zarówno moi jak i męża zostali w kraju. Koledzy i koleżanki to jednak nie to samo. Nie było ludzi, których człowiek tak bardzo kochat. I tego brakowało w życiu dobre pięć lat. Człowiek byt sam. Dużo, dużo pragnat w życiu osiagnać, nie było łatwo, ale to, paradoksalnie, robito człowieka silnego, odpornego na różne losowe przeciwności i zdarzenia (Darek, lat 33).

${ }^{13}$ M. Plopa, Psychologia rodziny: teoria i badania, Kraków 2005, s. 83. 
Myśle, że to, co mi pomogło, z czego korzystałem i właściwie korzystam do dziś, co też staram się pielęgnować w mojej obecnej rodzinie, myśle, że... to ciepło, ciepto rodzinne, otwartość, szczerość. Nawet jak czasami prawda boli, to zawsze jest lepiej, żeby powiedzieć, niż nosić w sobie i potem kiedyś, w jakimś momencie wybuchnać. Później się już tak nie przekaże, jakby się chciało. Hmm... (westchnienie). To mam $z$ własnej rodziny, $z$ własnego domu (Maciej, lat 32).

Autorzy narracji wskazują, że dom rodziny to dla nich obszar zapewniający wsparcie, pomoc, bezpieczeństwo. Wspomnienie atmosfery panującej w domu rodzinnym, pamięć o rodzinie jako miejscu otwartych, ciepłych, szczerych, autentycznych relacji stanowi istotny czynnik dający wewnętrzną siłe do zmagań ze światem, z nieprzewidywalnymi, trudnymi sytuacjami, które przynosi życie emigracyjne. Jak wynika z wypowiedzi jednego z rozmówców, najdotkliwszym odczuwanym brakiem w nowej sytuacji życia był właśnie brak rodziców. Pomimo dorosłości i gotowości podjęcia odpowiedzialności za samodzielne życie staje się to dotkliwie odczuwanym poczuciem samotności, czymś, czego nie można niczym zastąpić. Relacje z innymi, z kolegami nie wpisują się w przestrzeń bliskich więzi, których wzorzec został ukształtowany w rodzinie. Warto jednak przy tym zwrócić uwagę, że, jak to zostaje podkreślone w narracji, prowadzi to, "paradoksalnie”, do uzyskania większej, wewnętrznej siły, staje się okolicznością, która uodparnia na różne wyzwania i trudne sytuacje. Można ponadto, na podstawie wypowiedzi autorów narracji, skonstatować, że wyniesiony z rodziny pochodzenia obraz samego siebie, model domu rodzinnego oraz własnego $\mathrm{w}$ nim funkcjonowania wpływa w dużym stopniu na samoocenę i sposób życia w rodzinie, którą jednostka tworzy. Daje się tutaj zauważyć silna pod tym względem zależność. Pamięć o własnej rodzinie, o strukturze wewnętrznej domu rodzinnego staje się w kontekście emigracyjnych wyzwań silnie dochodzącą do głosu praktycznie aplikowaną hermeneutyką aksjologiczną, wpływającą na konkretne wybory i decyzje. Dotyczy to również strategii i mechanizmów radzenia sobie z trudnościami. Niekiedy doświadczenia i przeżycia wyniesione z domu rodzinnego osadzają się w świadomości jako złe wspomnienia i swego rodzaju blokady rozwojowe, jako dziedziczony nieprawidłowy, dysfunkcjonalny i niespójny przekaz odnoszący się do rzeczywistości życia rodzinnego.

Jeśli chodzi o to, co mnie osłabia w życiu codziennym... (dłuższa pauza) to myśle, że są to jakieś moje własne, osobiste wspomnienia z przeszłości, z rodziny, które czasami mnie doganiaja, a z wiekiem coraz bardziej, a którymi wiem, że muszę się zając, by móc tutaj żyć w rodzinie, w szczęściu. Chyba moja przeszłość mnie dogania, jakieś lęki z rodziny $i$ wiem, że przed tym nie ucieknę, że będę musiała się tym bardziej świadomie zająć... (pauza). Bolesnym doświadczeniem było to, 
że nie mogłam, kiedy miałam lat dwanaście, trzynaście, czternaście rozmawiać na różne tematy, które sa tak ważne dla dziewczynek w tym wieku (dłuższa cisza). I bolesne, po dzień dzisiejszy jest to, że ten czas pozostawił głęboki ślad na relacjach moich i mojej rodziny. Po dzień dzisiejszy (dłuższa cisza). Bolesne jest to, ze nie moge... (wzruszenie). Więc bardzo bolesne po dzień dzisiejszy jest to, że nie umiemy w mojej rodzinie, czyli rodzice i moi bracia i ja rozmawiać na temat tych dawnych lat, lat rozłaki i lat jakby zbliżania się do siebie i leczenia tego pęknięcia. Myślę, że pęknięcie w naszej rodzinie pozostało po dzień dzisiejszy (cisza). Wniektórych miejscach to zawsze było kruche naczynie, któremu groziło rozbicie i to peckniecie jest nadal. Nigdy nie doszło do rozmowy później, choć tyle lat minęło i mam olbrzymia nadzieje, może idealistyczna, całkowicie nierealna, że kiedyś dojdzie do takiej rozmowy, choć nie wiem, czy to jest możliwe, realne (wzruszenie). Mam takie wielkie pragnienie porozmawiania z moimi rodzicami na temat właśnie tego czasu, tych decyzji, ale też tego, co oni przeszli w tym czasie, w taki szczery sposób, a także rozmowy z moimi braćmi. Niestety, do tej pory takich rozmów nie było, nie ma. Nie wiem, czy w ogóle kiedykolwiek stanie się to możliwe, ale bardzo bym tego chciata. To jest dla mnie bardzo ważne, ponieważ widze, jak wiele z przeszłości, to o czym nie wiem, wpływa na moje obecne życie $i \dot{z}$ ycie mojej obecnej rodziny (Lucyna, lat 34).

Przedstawione fragmenty wypowiedzi stanowią egzemplifikację pojawiającego się w narracjach wątku dotyczącego doświadczenia i obrazu domu rodzinnego. Można zauważyć, jak bardzo owa „podmiotowa, wewnętrzna perspektywa"14 tworzy reprezentację tematu, odzwierciedla indywidualny, bardzo osobisty sposób rekonstruowania łączących się z nim znaczeń i sensów oraz wpisuje je w ścisły związek z emigracyjnym kontekstem życia. Narracje ukazują korelację posiadanego, głęboko zinterioryzowanego obrazu domu rodzinnego z doświadczanym momentem życia, z percepcją emigracyjnego "tu i teraz".

\section{BIBLIOGRAFIA}

Cierpka A., Narracyjna tożsamość jednostki a funkcjonowanie systemu rodzinnego, [w:] Narracja. Teoria i praktyka, red. B. Janusz, K. Gdowska, B. de Barbaro, Wydawnictwo Uniwersytetu Jagiellońskiego, Kraków 2008.

Cierpka A., Tożsamość i narracje w relacjach rodzinnych, Wydawnictwo Psychologii i Kultury Eneteia, Warszawa 2013.

Grzymała-Kazłowska A., Konstruowanie „innego”. Wizerunki imigrantów w Polsce, Wydawnictwa Uniwersytetu Warszawskiego, Warszawa 2007.

Niedźwiecki D., Migracje i tożsamość. Od teorii do analizy przypadku, Zakład Wydawniczy Nomos, Kraków 2010.

${ }^{14}$ M. Straś-Romanowska, Psychologiczne badania narracyjne, s. 61. 
Plopa M., Psychologia rodziny: teoria i badania, Oficyna Wydawnicza Impuls, Kraków 2005.

Straś-Romanowska M., Psychologiczne badania narracyjne jako badania jakościowe $i$ ich antropologiczne zaplecze, [w:] Narracja. Teoria i praktyka, red. B. Janusz, K. Gdowska, B. de Barbaro, Wydawnictwo Uniwersytetu Jagiellońskiego. Kraków 2008.

Teusz G., Biograficzna pamięć i tożsamość rodziny, [w:] Rodzina - tożsamość - pamięć = Family Identity - Memory, red. M. Kujawska, I. Skórzyńska, G. Teusz, Wydawnictwo Wyższej Szkoły Nauk Humanistycznych i Dziennikarstwa, Poznań 2009.

Teusz G., Tożsamość narracyjna rodziny wobec multiinformacyjnej kultury wspótczesności, [w:] Kultura popularna w społeczeństwie wspótczesnym. Teoria i rzeczywistość, red. J. Drozdowicz, M. Bernasiewicz, Oficyna Wydawnicza Impuls, Kraków 2010.

Teusz G., Rzeczywistość budowana stowami. Narracja jako proces wspóttworzenia tożsamości rodziny polskiej na emigracji, [w:] Badania biograficzne i narracyjne w perspektywie interdyscyplinarnej. Aplikacje - Egzemplifikacje - Dylematy metodologiczne, red. M. Piorunek, Wydawnictwo Naukowe UAM, Poznań 2016.

Trzebiński J., Problematyka narracji we wspótczesnej psychologii, [w:] Narracja. Teoria i prakty$k a$, red. B. Janusz, K. Gdowska, B. de Barbaro, Wydawnictwo Uniwersytetu Jagiellońskiego, Kraków 2008. 